\title{
Grandiose Type Delusional Disorder
}

National Cancer Institute

\section{Source}

National Cancer Institute. Grandiose Type Delusional Disorder. NCI Thesaurus. Code C94383.

A subtype of delusional disorder characterized by the central delusional theme that the individual has special worth, power, knowledge, or a special relationship to a famous person or deity. 